\title{
Government in Nigeria Can Achieve Good Governance Through Good Management
}

\section{John Nkeobuna Nnah Ugoani}

Department of Management Sciences College of Management and Social Sciences, Rhema University, Nigeria Email: drjohnugoani@yahoo.com

\author{
Article History \\ Received: August 5, 2020 \\ Revised: August 27, 2020 \\ Accepted: September 7, 2020 \\ Published: September 10, 2020 \\ Copyright @ 2020 ARPG \& \\ Author \\ This work is licensed under the \\ Creative Commons Attribution \\ International \\ (9) (1) CC BY: Creative \\ Commons Attribution License \\ 4.0
}

\begin{abstract}
Poor public management defined by corruption and lack of prudence in public life continues to hold Nigeria hostage and makes good governance difficult. Since the 1980s government has been using many methods including the processes of privatization and commercialization as means of re-engineering the public sector for total quality management, and to increase the share of the public sector's contribution to the gross domestic product. The experiment never achieved the desired level of success partly due to lack of political will on the part of government to wedge a total war against corruption, and also partly because the public sector is a large scale administration that has many entry and revolving doors which government finds difficult to close. These limitations provide the incentives for widespread public corruption that is recognized as one of the greatest challenges of government in carrying out its mandate. 110 respondents participated in this study conducted through the exploratory research design. The participants provided useful data that were triangulated with data from secondary sources for the purpose of the study. To achieve the objective of the investigation, data were analyzed through statistical techniques and the result showed significant positive correlation between good governance and good management. It was recommended that appointments in the public sector should feature a combination of people from private and public sectors of the economy to enhance competence with the aim of reducing public sector corruption. Further study should examine the reasons behind rising budget deficits as a way of reducing cost of governance in Nigeria.
\end{abstract}

Keywords: New public management; Emotional intelligence; Widespread public corruption; Re-engineering the public sector; Large scale administration; Prudence; Sustainable services; Poverty; Corporatization; Administrative irresponsibility.

\section{Introduction}

Management relates to the processes of achieving results in a systematic way and within the constraints of limited resources. Therefore, the aim of good management is to increase productivity, effectiveness, efficiency or to reduce cost of doing business, public administration, or governance. Management or administration is carried out within any human organization. In this perspective, the entire society could be regarded as an organization. Management is a universal activity common to society, whether it is public or private. For example, public administration is often used interchangeably with public management, public governance, or with other concepts such as government administration, and public sector management. However, public administration is specifically concerned with the affairs of the state. For instance, every state has a government which is responsible for its administration. This is why public administration is usually called government administration. The organization of the state determines the levels of public administration. In a country like Nigeria, with three tiers of government, there are three levels of public administration: federal, state and local governments. On the other hand, public management is a large scale organization carried on by government or its agency. According to Nwizu (2002), to manage such large scale organization, government needs finances that come from certain specified sources which are to be used for carrying out certain specific activities only. He opines that in the absence of such an exercise, neither will it be possible for the government to determine the sources of fund nor will it be possible for the government to establish the priorities in which different activities are to be performed. In the circumstance, government carefully plans its financial resources over realistic estimates of proposed income and expenditure through the budget system. This suggests that there is need for corruption-free-management or new public management to reduce cost of governance in Nigeria. The new public management (NPM) paradigm seeks to improve the performance and efficiency of government business. According to McCourt (2008) it means to achieve greater efficiency, cost saving or service quality improvement, in which case, it is accompanied by setting performance targets for the executive. According to Tshiyoyo (2012), while public administration is an enabling activity on a continuous basis, by contrast, 
public management is a continuing activity, and the ongoing continuation of activity, made possible by public administration. The case for NPM as a measure for reducing cost of governance is reinforced by its market-based model defined within the framework of prudence, efficiency, competence, innovation and characterized by quality leadership to ensure accountability, transparency, performance and sustainability of basic services. According to Girishankar et al. (2002) accountability and transparency provide strong incentives for good governance. They are essential characteristics of well-functioning institutions, and good public sector performance. Lack of prudence in public management explains why huge public resources are wasted through corruption. Corruption inflates cost of governance and does not allow the government to provide basic services to the people. As the result of dwindling resources, high poverty levels and the rising cost of public governance, scholars like (Mabikke, 2012) suggests that one of the major characteristics of weak governance is corruption. While governance denotes the use of political authority and exercise of control in a society in relation to the management of its resources for social and economic development, management denotes the careful and efficient employment and utilization of resources. Therefore, weak governance often measured by high cost of governance would suggest that public resources are not efficiently and effectively utilized. Since corruption is highly correlated with inefficiency, it becomes safe to suggest that corruption more than any other factor is behind high cost of governance in many developing countries like Nigeria. Therefore, on the issue of cost of governance in Nigeria for example, Egburonu (2019) reports that in the first civilian administration in the post-independence era as well as under the military regimes, there was marked conspicuous absence of bloated parliamentary structures. However, he insists that while military regimes represent aberrations and cannot, therefore, serve as a yardstick for a useful model for measuring cost of public governance, identifying the challenges requires a deep understanding of the underlying causes. He points out clearly that policy slippages, and widespread public corruption help to push up cost of governance. Tackling the problem of high cost of governance in Nigeria will then mean having the political will to fight corruption. For example, it is almost agreed that Nigeria does not have an effective public administration. This situation is responsible for its poor budget administration and implementation. Budget as a tool of management is a system through which all the financial affairs of the state are regulated. It is through the budget system that the executive arm of government plans realistic estimates of income and expenditure necessary for effective public governance. Emphasizing management perspectives on reduced cost of governance is critical because management generally involves the co-ordination of institutional resources and harnessing them, reducing cost and maximizing benefits. To this extent, governance relates to the capacity of governments to manage resources efficiently and to formulate, implement, and enforce sound policies and regulations for public good. Therefore, governance is the sum of the many ways by which individuals and institutions, whether public or private, manage their common affairs. It is a continuous process through which conflicting or diverse interests may be accommodated and co-operative action may be taken. Governance emphasizes the role of public authorities in establishing the environment in which economic resources are to be effectively managed in determining the distribution of benefits as well as the relationship between the leader and the led. Accordingly, the effective management of public affairs becomes the catalyst for reducing cost of governance. These perspectives postulate that with the proper level of political will, the legislature and the government leaders can efficiently and independently police and firmly enforce public policies to establish and sustain strong public institutions that will receive public confidence critical to the sustenance of democratic governance (Hammergren, 1998). It is very important to explain that in curbing public corruption and in pursuit of public accountability and transparency, understanding the dynamics of public sector management through regulatory legislation is imperative. In the circumstance, therefore, DeLozada (1999) opines that there must be laid down regulatory or administrative mechanisms developed to enhance public sector management to the extent that would lead to reducing cost of governance. Contemporary literature on natural resources management in oil rich African states like Nigeria, suggests that reducing cost and achieving success in democratic governance require a combination of good institutions and reducing corruption. For example, according to Njoku (2009) efficient financial management is crucial to cost reduction and rational allocation of scarce resources between competing and conflicting interests. He also emphasizes that efficient or improved financial management helps to resolve the problems of lack of public accountability and administrative irresponsibility. Also non-compliance with the statutory requirements of financial memoranda and general budget indiscipline, inflation of public contracts, prices, procurements, payment for non-executed projects; exacerbate cost of public administration. Tstsu (2016) finds that resource-rich West-African countries like Ghana, Nigeria, and Cote-d Ivoire are experiencing a recurring high debt status which is characterized by corruption, fiscal indiscipline, and poor leadership that is seriously worsening their underdevelopment status as independent states (Jibueze et al., 2019; Jimoh and Akuba, 2019; Nweze, 2019a;2019b; Ofikhenua, 2019a;2019b; Okpalike, 2018; Onogu, 2019; Orekoya, 2019; Otokpa, 2019`; Transparency International, 2006).

\subsection{Research Problem}

The challenge of management is cost minimization and the maximization of benefit. In this context, therefore, reducing cost of public governance will greatly depend on minimizing public corruption, incompetence and inefficiencies associated with public management. Cost of governance in Nigeria is high not only because of the huge benefits of the legislators and the leaders of government, but it is also positively correlated with the problems of endemic public corruption. Corruption is pushing up cost of governance through its many faces and simultaneously undermines the potency of government and highly jeopardizes the status of the massive poor in society. Even though Nigeria may not be the most corrupt country in the universe, but it is acquiring the worrying status of a formidably corrupt country characterized by cases like sharing public cash by public officers up to about 
N3bn, reckless \$16bn power sector spending, suppression of about N10trillion through the wage system, and including the use N14bn public funds by a former minister to purchase jewelry for personal use; while in public office. In other oil-rich countries, corruption in the power sector is also worrisome. To this extent, Gulati and Rao (2007) campaign that curbing corruption in the electricity sector requires committed leadership at the top. A change process requires a champion for change, and a core team backed by necessary resources to build and sustain support. For example, the Mambilla Hydro Project in Nigeria that has been on the drawing board for about 60 years requires a core-team and not a corrupt-team for its realization. It is now labeled a cash-cow for some corrupt government officials because of common neutralizing tactics like not adequately disseminating information to the public about the laws establishing it and depriving the project of necessary budget to run. Curbing corruption and reducing cost of governance require political leadership that is prepared to institutionalize appropriate legal and regulatory frameworks to carry its projects and to appoint persons of proven integrity and ability to key public management positions. Implementation of anti-corruption strategy may amount to a major cultural and attitudinal change in public governance and public management, therefore, government may begin with a campaign to mobilize the support of the passive majority, and use deft political management to succeed. The challenge of corruption or mismanagement phenomenon makes the focus of attention in the areas of public management or NPM crucial for reducing cost of governance. The starting point is the agreement by scholars that good public management characterized by the three "Es" - economy, efficiency, and effectiveness-holds the key (Aucoin, 1990; Beschel, 1995; Bissessar, 1998; Borins, 1994; Brown, 1999). In a country where allegations are rife that past presidents asked for kickbacks for giving contracts, where public officers take double pay, engage in illegal investigations, and where huge contracts are raised just to be loopholes for personal gains, are bad and increase cost of governance while the people remain in absolute poverty. As of 2018, it was estimated that Nigeria is the country with the most people living in extreme poverty, at 86million in sub-Saharan Africa (Adekoya, 2019; Balogun, 1983; Malami, 2019; Nkwopara, 2019; Shehu, 2019). Among the major worrisome issues about public management and high cost of governance in Nigeria include the levels of deficit budgets and the so-called budget padding. Budget padding does not only reflect poor public management it is also a matter of public corruption. These, including the problem of huge foreign loans with the accompanying principal and interest payments will always jack up cost of government business and governance. Mailafia (2019) for example, does not believe that Nigeria is exercising enough financial discipline with regard to expenditure controls, and thinks that there is need to be cautious of loans that the nation cannot afford to pay back (Umoru, 2019). The scandal of ex-governors drawing as much as N10million monthly as pensions, even while serving as ministers or senators, is crazy and unbelievable, and cannot help in reducing cost of governance in Nigeria (Baje, 2019; Eriye, 2019a;2019b; Oyesola, 2019; Paiko, 2012; Sanusi, 2019; Sobowale, 2019; Soyele, 2019; Stephen, 2019; Utomi, 2019).

\subsection{Research Objective}

The study was designed to explore the relationship between good management and good governance in Nigeria.

\subsection{Research Questions}
i. Is prudence an element of good management?
ii. Can good management lead to good governance?
iii. Is planning related to good management?
iv. Can competence lead to good governance?
v. Does innovation form an important task of government?

\subsection{Hypothesis}

To realize the objective of this investigation, the following hypothesis was formulated and tested at 0.05 level of significance..

Ho: There is no relationship between good management and good governance.

Hi: There is a relationship between good management and good governance.

\subsection{Research Significance}

At a time of dwindling economic fortunes scholars and the public have become worried over the rising cost of governance in the midst of poverty. Finding a way out of the quagmire can only start from finding its origin. In this regard, it becomes significant to stress that the challenges of widespread public corruption can thwart the capacity of public management, undermine the potency of government and easily escalate cost of governance. Therefore, reducing cost of governance will largely depend on prudential public management with zero-tolerance for corruption.

\subsection{Conceptual Framework}

A conceptual framework shows the structure of the study and its main variables. It also describes its relationship with the research problem. This is usually expressed in a schematic model. According Cleary (1992) models are effective research tools and they are crucial in theory building. Models are importantly used to explain, clarify and draw attention to issues that would otherwise be buried in an excess of words (Keeves, 1997; Meredith, 1993). Figure 1 showed the conceptual model for the present study. 
Business, Management and Economics Research

Figure-1. Good Management and Good Governance Model

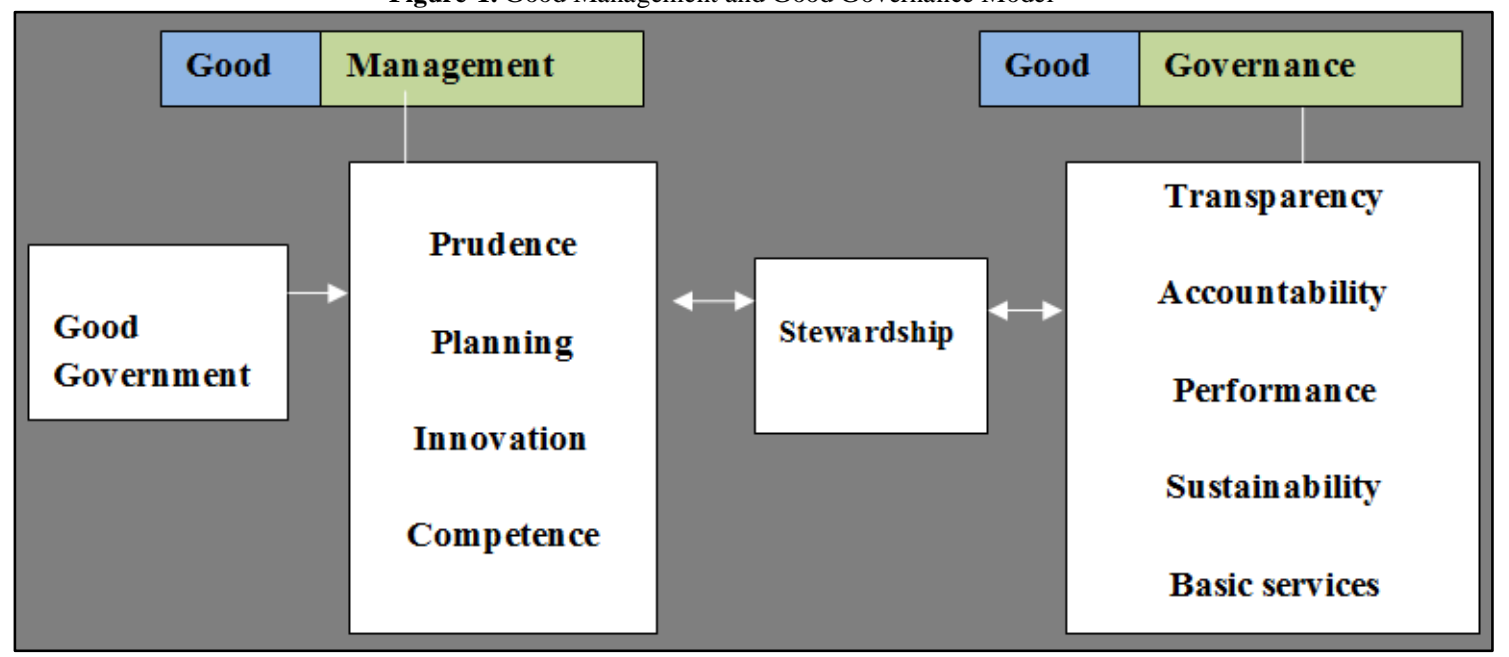

Source: Author Designed (2020)

In the fierce competitive global imperatives characterized by shrinking public finances, rising cost of government business and public governance, it is now the thinking that good management is crucial more than ever before in reducing cost of governance. Good public management characterized by prudence, planning, innovation, and competence among others, will no doubt demonstrate a passion for public infrastructures, employment, security and national stability (Yu and Lee, 2012). Good public management and public governance belong to different sides of the same coin. Prudent public management is expected to stay aside from corruption which impedes the power of government to reduce cost of governance and provide good governance. The need of good public management is efficient, effective and economical management of public resources to achieve public welfare. Public welfare will be short without infrastructures, employment, security and stability. Different types of reforms, in many developing countries have failed to reduce corruption and cost of governance. Therefore, even if NPM does not provide the answer, it can bring a paradigm shift towards the desire to reduce corruption and cost of governance in developing nations. Although McCourt (2008) believes that the assumption of NPM is universal, it is a departure from the vocabulary of civil service reforms all over the world. He emphasizes that even with it, the search for a solution to the problems of governments in developing countries requires open-mindedness and collaboration. Management with passion for service gives rise to good governance defined by stewardship within the framework of integrity, transparency, accountability and probity and a corruption-free political system (Blanchard, 1999; Block, 1993). The NPM argument focuses towards efficient management that would enhance enforcement and compliance with ethical standards to promote good governance, with good government as the chief driver. Ethical standards suggest that at all times, people should act with honesty, whether in public or in private affairs and uphold the highest ethical behaviours so that the public confidence and trust in the capacity, objectivity and impartiality of government can be enhanced. According to Maduabum (2006) the principle of accountability and transparency stresses that public officers should demonstrate an overriding responsibility to the public interest, which requires that they set aside all personal, sectional and regional interests for the public interest. To this extent, they should be open to public scrutiny and should as far as possible, be open and transparent in the discharge of public duties and also encourage others to follow the example. The NPM perspective is a direct response to common pressures; public hostility to government, shrinking budgets, the imperatives of globalization and the need for performance-based government (Badarocco, 2002; Tsa, 2019).

\section{Literature Review}

At whatever level, management is involved in creation of wealth. Management creates wealth through promoting efficiency. Like economics, management is involved in the allocation of scarce resources to achieve objectives. Management focuses on the co-ordination of institutional resources and harnessing them with the view to maximizing organizational or institutional goals effectively. NPM or corporatization is also a way of freeing a particular public function from the constraints of civil service red-tape. The NPM concept emphasizes efficiency and effectiveness, and this is necessary to reduce cost of governance. Reducing cost of governance requires sound public management characterized by sound fiscal management and public policy. Sound financial management constitutes an important pillar of sound governance architecture that entails timely reporting and comprehensive budget as well as transparent procurement procedures. Kaufmann and Dininio (2006), explain that alongside good financial management practices, sound revenue collection mechanism is another pillar of good government. Dorokinsky and Pradhan (2007), suggest that strengthening transparency and accountability is key to reducing cost in public affairs. They opine that weak management, supervision, weak transparency and accountability, limited capacity to detect and monitor corruption, and limited enforcement capabilities also give rise to significant opportunities for corruption in public management. Therefore, management control and oversight can provide a strong deterrence to fraudulent behaviours, corruption, and bad governance (Chiejina, 2019; Ugo, 2018; Wantu and Ogunu, 2019; Ware et al., 2007; Yusuf and Chiejina, 2019). 


\subsection{Corruption}

Marshall (2006), opines that strong parliamentary oversight is an essential part of combating corruption and ensuring good governance. He points out that there are many oversight tools in parliamentary systems to ensure that projects are carried out legally, efficiently, effectively, and for the purposes for which they were intended. According to him, there should be sufficient opportunity for ministers and leaders of government to be publicly accountable. Reducing cost of governance therefore, and simultaneously promoting good governance, requires that the capacity of oversight committees to review policies, programmes and operations, should be increased where necessary, and all subordinate legislations must be scrutinized to ensure consistency with parliamentary Acts. Doig (1999), explains that every society harbours some forms of corrupt activities of public officials which can destroy the potential effectiveness of all types of governmental programmes, and hinder development. He emphasizes that governance, therefore, incorporates not only the integrity, efficiency, and economy of government, but also its effectiveness as measured by the ends to which government organization and activity are directed. In the circumstance, reducing cost of governance, depends on public accountability and effective leadership (Abuh, 2019; Akowe, 2019; Akubeze and Umoh, 2019; Alli, 2019a;2019b;2019c; Ehiaghe, 2019; Folasade-Koyi, 2019).

\subsection{Responsibility}

According to Williams (2006) essentially, a parliament has four fundamental responsibilities in the exercise of the oversight of government. These include to debate, modify, approve or reject legislation, to debate, modify, approve, or reject authority for government to raise revenues through taxation and from other means, to debate, modify, approve, or reject proposed expenditure, by government, and to hold the executive accountable by its governance of society. According to him, in a properly functioning democracy, a government is accountable to the parliament as a whole, where the members bring a diversity of opinion to any debate, but parliament should exercise its considered judgment on the proposals by government and the performance of government. The parliament as a whole must not think that their role is to support the government at any cost, particularly if they are a member of a ruling party or to oppose the government proposals, where they are a member of the opposition party. Legislators rather, should see themselves as people who have been chosen by their people to represent their views and to demand transparency, accountability and performance from government through effective oversight-functions because government theoretically reports to parliament. But legislators can maintain effective networks as catalyst for reducing corruption and cost of governance, because their opinions are often and actively sought for. Thus, if legislators from different political parties sing from the same hymn book, it makes a greater impact than the opinion of one politician (Andreychuck and Jennings, 2003; Cossey, 2000),. Always, parliamentary networking is critical to enhance good governance because fighting corruption cannot succeed by a lonely voice, particularly where a corrupt executive influences parliament, and even the judiciary. In a situation where responsibility is compromised, corruption pushes high cost of governance. The principle of responsibility is fundamental to the functions of public officers, like the attorney-general of the federal (AGF). For example, in Nigeria, Section 150(1) of the Constitution of the Federal Republic of Nigeria (1999) (as amended) provides that there shall be an AGF who shall be the Chief Legal Officer of the Federation and a Minister of the Government of the Federation. Same applies to the states. The Constitution envisages that the AGF has the responsibility of enforcing laws which is critical to the entrenchment of the principle of rule of law necessary to protect public right or performance of public duty, and to enhance good governance. Responsibility is therefore, critical to good public management and governance because public administration is responsible for all its acts to the political executive who in turn; is responsible to the public through the legislature. It is also important for accountability because it is only when an official is responsible for an act or duty that he or she can be asked to give account of his or her performance (Njoku, 2017).

\subsection{Management and Governance}

Governance broadly refers to the exercise of power through a country's economic, social, and political institutions in which institutions represent the rules and routines, formal laws, and informal norms that together shape the incentives of public policy makers, overseers and providers of public services. Three key dimensions of governance include; the process by which governments are selected, held accountable, monitored and replaced, the capacity of governments to manage resources effectively and to formulate, implement, and enforce sound policies and regulations, and respect for institutions that govern economic and social interactions. Also, governance architecture involves the use of political authority and exercise of control in a society in relation to the management of its resources for social and economic development. This emphasizes the role of public authorities in establishing the environment in which economic resources and funding are efficiently managed in determining the common good. Weak macroeconomic management often promotes the exigencies for budget deficits which in turn escalates cost of governance. For example, Saad and Kalakechi (2009) explain that budget deficits represent a demand for funds by the government which must be met through an excess of domestic saving over investment and by external borrowing, or from taxation and or the use of relevant monetary policy (Ebimobowei et al., 2013). For example, in the past 30 years, budget deficits in Nigeria had risen steadily from N15,134.70 million in 1989 to N9.12tr for 2020 fiscal year (Jimoh and Akuba, 2019). With the consequent debt and interest payments, the ability of government to formulate and manage purposeful expenditure and revenue budget will help in reducing rising cost of governance in Nigeria (Chigbo, 2003; Clark, 2019; Dare, 2019). 


\section{Research Methodology}

The exploratory research design was adopted for the study. The quantitative and qualitative techniques of the exploratory design can be used in exploratory study (Cresswell, 2009).

\subsection{Population, Sample and Size}

The population comprised of the people in Nigeria. The sample was selected through the judgmental method, while the size was determined by the sample ratio concept (Obodoeze, 1996).

\subsection{Data Collection Method}

Data were generated from secondary and primary sources such as: books, journal articles, government bulletins, newspapers, magazines, personal interviews, discussions, observations, among others. This method was adopted so as to supplement and complement data through each other. Data generated were triangulated, organized and coded in readiness for analysis.

\subsection{Decision Rule}

The decision rule for the mean cut-off point for the analysis of responses to the research questions was at 3points. According to Nwankwo (2011) this method is appropriate to analyze answers to research questions.

\subsection{Data Analysis}

Data were analyzed through descriptive and regression statistical techniques. The Ordinary Least Square (OLS) method was employed for the regression analysis. OLS technique is a method used to estimate the unknown parameter in a linear regression model with the goal of minimizing the differences between observed variances in a dataset. The method was not chosen because of its simplicity, but also because of its unique properties of linearity, efficiency, sufficiency, least variances, unbiasedness and least mean errors. The F-test and t-test were used to determine the overall adequacy of the regression model using the E-View Statistical Package (Edmondson and McManus, 2007).

\subsection{Model Specification}

Model specification is the expression of a relationship into precise mathematical form. According to Koutsoyainnis (1977) economic theory does not indicate the functional form of any relationship. This means that economic theory does not state whether a relationship will be expressed in linear form, quadratic form, or in a cubic form. On the basis of these, it was decided to specify the relationship between Good Governance (GG) and Good Management (GM) as:

$\begin{array}{lll}\mathrm{GG}=\mathrm{b}_{0}+\mathrm{b}_{1}, \mathrm{PR},+\mathrm{b}_{2}, \mathrm{PL}_{1},+\mathrm{b}_{3}, \mathrm{IN},+\mathrm{b}_{4} \mathrm{CO},+\mathrm{t},+\mathrm{u} \\ \text { Where: } & = & \text { Good Governance } \\ \mathrm{GG} & = & \text { Prudence } \\ \mathrm{PR} & = & \text { Planning } \\ \mathrm{PL} & = & \text { Innovation } \\ \mathrm{IN} & = & \text { Competence } \\ \mathrm{CO} & = & \text { Constant term } \\ \mathrm{b}_{0} & = & \text { Coefficient attached to explanatory variables } \\ \mathrm{b}_{1}, \mathrm{~b}_{2}, \mathrm{~b}_{3}, \mathrm{~b}_{4} & = & \text { Time period } \\ \mathrm{t} & = & \text { Stochastic error term. } \\ \mathrm{u} & = & \end{array}$

\section{Presentation of Result}

Table-1. 20 Selected Corruption Issues (2020)

\begin{tabular}{|c|c|c|c|c|}
\hline $\mathbf{S} / \mathbf{N}$ & Description & $\mathbf{N}$ & U\$ & Status \\
\hline 1 & $\begin{array}{l}\text { Allegations of corruption against the former } \\
\text { Head of Service of the Federation. }\end{array}$ & $3 b n$ & & Under EFCC investigation. \\
\hline 2 & $\begin{array}{l}\text { Allegations of corruption in power sector } \\
\text { spending }\end{array}$ & & $16 b n$ & Under EFCC investigation \\
\hline 3 & $\begin{array}{l}\text { Fraudulent gas supply and processing } \\
\text { agreement (GSPA) }\end{array}$ & & $9.6 \mathrm{bn}$ & Under investigation / litigation \\
\hline 4 & Estimated six months loss to oil thieves & & $1.5 \operatorname{trn}$ & Cost of oil thieft in six months. \\
\hline 5 & Recoveries by EFCC from tax saboteurs & $28.5 \mathrm{bn}$ & $\begin{array}{l}77.83 \\
\mathrm{~m}\end{array}$ & $\begin{array}{l}\text { Recovered by EFCC / joint } \\
\text { taskforce. }\end{array}$ \\
\hline 6 & $\begin{array}{l}\text { Recoveries by FGN through integrated payroll } \\
\text { and personnel system information (IPPIS) }\end{array}$ & 10 trn & & $\begin{array}{l}\text { Saved through the treasury single } \\
\text { account \& IPPIS }\end{array}$ \\
\hline 7 & $\begin{array}{l}\text { Money stolen from Africa yearly with Nigeria } \\
\text { as the greatest contributor }\end{array}$ & & $50 \mathrm{bn}$ & To corruption yearly from Africa \\
\hline
\end{tabular}


Business, Management and Economics Research

\begin{tabular}{|c|c|c|c|c|}
\hline 8 & $\begin{array}{l}\text { Abandoned NDDC projects and allegations of } \\
10-20 \text { percent kickback }\end{array}$ & $80 \mathrm{bn}$ & & $\begin{array}{l}\text { Under House of Reps, } \\
\text { investigation }\end{array}$ \\
\hline 9 & $\begin{array}{l}\text { Allegations of corruption involving SIP } \\
\text { Officers }\end{array}$ & $22 \mathrm{bn}$ & & Under EFCC investigation \\
\hline 10 & $\begin{array}{l}\text { Part of huge stolen pension cash recovered } \\
\text { from Maina's Niamey home }\end{array}$ & & $1.7 \mathrm{~m}$ & $\begin{array}{l}\text { Stolen cash recovered from ex- } \\
\text { top public officer }\end{array}$ \\
\hline 11 & Abuse of office by an ex-minister & $14.4 \mathrm{bn}$ & & $\begin{array}{l}\text { Jewellery, others acquired while } \\
\text { in public office }\end{array}$ \\
\hline 12 & Irregular pull call option agreement on power & & $1.2 \mathrm{bn}$ & $\begin{array}{l}\text { 450mw power contract in Edo } \\
\text { State }\end{array}$ \\
\hline 13 & $\begin{array}{l}\text { Imo Assembly probes missing rural roads } \\
\text { equipment }\end{array}$ & $3 b n$ & & Under House probe \\
\hline 14 & Allegations of budget padding & $14 \mathrm{bn}$ & & $\begin{array}{l}\text { Alledged budget padding in } \\
\text { favour of a private company }\end{array}$ \\
\hline 15 & Loss to oil theft & & $42 \mathrm{bn}$ & $\begin{array}{l}\text { Amount lost to oil theft in } 10 \\
\text { years }\end{array}$ \\
\hline 16 & Loss to 10 Cs through PSC & & $62 \mathrm{bn}$ & $\begin{array}{l}\text { Estimated loss in } 15 \text { years in the } \\
\text { oil/gas sector }\end{array}$ \\
\hline 17 & Saving through IPPIS & $274 \mathrm{bn}$ & & $\begin{array}{l}\text { Saving through IPPIS between } \\
\text { 2017/2018 }\end{array}$ \\
\hline 18 & $\begin{array}{l}\text { Malabu oil deal involving Mr. Adoke, former } \\
\text { Minister }\end{array}$ & $288.6 \mathrm{~b}$ & & Under EFCC investigation. \\
\hline 19 & Estimated value of misapplied funds & 1 tr. & & $\begin{array}{l}\text { Misapplied constituency funds } \\
\text { under Reps investigation. }\end{array}$ \\
\hline 20 & $\begin{array}{l}\text { Estimated monthly drawing by } 47 \quad \text { ex- } \\
\text { governors and others }\end{array}$ & $37.4 \mathrm{~b}$ & & $\begin{array}{l}\text { The court has ordered the AGF } \\
\text { to institute proceedings for } \\
\text { recovery and prosecution. }\end{array}$ \\
\hline
\end{tabular}

Source: Fieldwork (2020)

Table-2. Profile of Respondents $(n=110)$

\begin{tabular}{l|l|l|l|l}
\hline S/N & Description & Category & Total & Percentage \\
\hline 1 & Gender & a) Male & 65 & 59.09 \\
& & b) Female & 45 & 40.91 \\
\hline 2 & Education & a) Diplomas & 25 & 22.73 \\
& & b) Degrees & 50 & 45.45 \\
& & c) Others & 35 & 31.82 \\
\hline 3 & Age & a) $18-35$ years & 70 & 63.64 \\
& & b) 36-70 years & 40 & 36.36 \\
\hline 4 & Experience & a) $5-10$ years & 30 & 27.28 \\
& & b) 11 - 20 years & 52 & 47.27 \\
& & c) 21 - 35 years & 28 & 25.45 \\
\hline 5 & Status & a) Low & 34 & 30.91 \\
& & b) Middle & 56 & 50.91 \\
& & c) High & 20 & 18.18 \\
\hline
\end{tabular}

Source: Fieldwork (2020)

Table-3. Analysis of Frequencies, Mean, Decision Mean and Grand Mean for Responses to Research Questions

\begin{tabular}{|c|c|c|c|c|c|c|c|c|c|c|c|}
\hline \multirow[t]{3}{*}{$\mathbf{S} / \mathbf{N}$} & \multirow{3}{*}{$\begin{array}{l}\text { Restatement of } \\
\text { Research Questions }\end{array}$} & \multicolumn{5}{|c|}{ Scores } & \multirow{3}{*}{$\begin{array}{l}\text { Row } \\
\text { score }\end{array}$} & \multirow{3}{*}{$\begin{array}{l}\text { No. of } \\
\text { Resps. }\end{array}$} & \multirow{3}{*}{ Mean } & \multirow{3}{*}{$\begin{array}{l}\text { Decision } \\
\text { Mean@ } \\
3 \text { points }\end{array}$} & \multirow{3}{*}{$\begin{array}{l}\text { Grand } \\
\text { Mean }\end{array}$} \\
\hline & & SA & $\mathbf{A}$ & $\mathbf{N}$ & D & SD & & & & & \\
\hline & & 5 & 4 & 3 & 2 & 1 & & & & & \\
\hline 1 & $\begin{array}{l}\text { Prudence is an element } \\
\text { of good management }\end{array}$ & 50 & 30 & $\overline{1}$ & 10 & 19 & 412 & 110 & 3.75 & Accepted & \\
\hline 2 & $\begin{array}{l}\text { Good management } \\
\text { does not lead to low } \\
\text { cost of governance }\end{array}$ & 10 & 20 & 3 & 17 & 60 & 233 & 110 & 2.12 & Rejected & \\
\hline 3 & $\begin{array}{l}\text { Corruption increases } \\
\text { cost of governance }\end{array}$ & 40 & 50 & 2 & 5 & 13 & 429 & 110 & 3.90 & Accepted & \\
\hline 4 & $\begin{array}{l}\text { Transparency is a sign } \\
\text { of good governance }\end{array}$ & 60 & 25 & 4 & 7 & 14 & 440 & 110 & 4.00 & Accepted & 3.22 \\
\hline 5 & $\begin{array}{l}\text { Innovation does not } \\
\text { lead to wealth creation }\end{array}$ & 15 & 25 & 2 & 8 & 60 & 257 & 110 & 2.34 & Rejected & \\
\hline
\end{tabular}

Source: Fieldwork (2020) 
Business, Management and Economics Research

Table-4. Regression Analysis

\begin{tabular}{l|l|l|r|l}
\hline \multicolumn{1}{c|}{ Variables } & Coefficient & Std. Error & t-Statistic & Prob. \\
\hline C & 3.781370 & 0.176810 & 23.78645 & 0.0000 \\
PRU. & -0.418015 & 0.245750 & -1.481972 & 0.1864 \\
PLN. & 0.281845 & 0.018219 & 22.97402 & 0.0065 \\
INN. & -0.008845 & 0.049689 & 0.483276 & 0.7680 \\
COM. & 0.017186 & 0.005787 & 2.187640 & 0.0585 \\
\hline R-squared & 0.860145 & Mean dependent & 1.767520 & \\
Adj. R-squared & 0.781470 & S.D. dependent v & 1.462081 & \\
S.E. of regression & 0.656582 & Akaike info criterion & 2.212155 & \\
Sun squared resid & 8.650624 & Schwarz criterion & 2.714421 & \\
Log likelihood & -22.22731 & Hannan-Quinn criterion & 2.538891 & \\
F-Statistic & 14.12004 & Durbin-Watson Stat & 2.194120 & \\
Prob (F-statistic) & 0.000002 & & & \\
& & &
\end{tabular}

Source: E-View Statistical Package

\subsection{Discussion}

Good public management or public governance should aim at effective deployment and utilization of public resources for the benefit of the majority. People are poor in society because of the inefficiency associated with pubic management and governance. Cost of governance is rising steadily in Nigeria not only because of the jumbo salaries and allowances of legislators and government leaders which rank among the highest in the world, but more because of bad management of public resources which results to bad governance. Bad management is the opposite of good management and is characterized by corruption, lack of prudence in the use of resources, lack of planning, fraudulent budgeting system, lack of innovation among other issues associated with lack of accountability and transparency, and therefore, the inability of government to sustain basic social services like: education, healthcare, infrastructure, and public transportation. Government can reduce cost of governance through the culture of good management reinforced by stewardship-leadership to harness public finances for productive use. Good public management would involve innovation in public office and to find new and better ways of doing government business, to block avenues for huge losses and create new ways to generate employment and revenue. For example, government spends huge amount of money on fuel and diesel to generate electricity, while power projects like the Mambilla power project has been on the drawing board since 1959. The money spent on buying gas daily increase cost of governance. When abandoned projects like the Ajaokuta Steel Complex, among others are renovated they would create employment for the huge unemployed population and thus, reducing cost of what is now called "social investment programme" (SIP) that weighs very highly on cost of governance. Nigeria has plenty deposits of bitumen, gas, gold, salt, steel, among others that are yet to be explored to increase sustainable revenue inflow to cushion the effect of budget deficits, bring down cost of external borrowing and governance. If the country continues to wait for the time the number of legislators would be reduced, instead of wedging a holistic war against widespread public corruption, squandamania and kleptomania, cost of governance will continue to rise. The catalogue of public corruption allegations as in table 1 justifies the assumption that corruption is a major cause of high cost of governance in Nigeria. A situation where public officers are unable to account for N3billion, and where \$16billion power sector spending remains unaccounted for would not provide any chance for good governance. As an oil-rich economy, public officers intentionally create bogus contracts like the \$9.6billion gas supply and processing agreement (GSPA) that was destined to fail would always reduce the disposable budget of government and the provision of essential services. Huge amounts of money are lost to oil thieves, while government goes cap in hand to borrow at high interest rates. Blocking porous avenues that create incentives for public sector corruption through systems like TSA, IPPIS, as well as reducing the discretionary powers of legislators and government leaders in contract bidding and public procurement arrangements would help in reducing public corruption and cost of governance. A country where a cabinet minister would use $\$ 14$ bn for personal jewelry does not portray the leadership as sensitive to its economic woes characterized by high levels of poverty and unemployment. Kickbacks at parastatals created to provide the platform for provision of social amenities and poverty reduction add up to increase cost of governance without achieving the objectives for which they were created. The constant issue of budget padding is a dangerous phenomenon in the face of rising budget deficits and the burden of loans and their repayment terms and conditions. Cost of borrowing and then cost of governance can be reduced drastically where such losses as $\$ 42$ billion to oil thieves are avoided and the sum of up to $\$ 62$ billion lost to IOCs can be recovered. These good management imperatives and the New Deep Offshore Act can help in minimizing cost of governance and lifting the nation out of the league of the Least Developed Countries (LDCs) of the world. Participants in the study were composed of 65 males and 45 females knowledgeable in the areas of interest. The psychometric model in figure 1 showed that good management driven by good government influences good governance through good stewardship. As described in table 2, the respondents held various academic qualifications like diplomas, and degrees, with industrial work experiences between 5 to 35 years, and ranging in age between 18 to 70 years. They were within the low, middle and high income levels. Their responses to the research questions were found useful for statistical analysis, as in tables 3 and 4 respectively. As in table 3(1) they accepted at 3.75 mean score that prudence is an element of good management. This supports McCourt (2008) that efficiency, economy and effectiveness are components of the NPM paradigm. In table 3(2) they did not accept at 2.12 mean score that good government does not lead to low cost of 
governance. This supports Kaufmann and Dininio (2006) that good public management is key to good governance. At 3.90 as in table 3(3) they accepted that corruption increases cost of governance. This response gives credibility to Girishankar et al. (2002) that accountability and transparency provide strong incentives for good governance. They also agreed at 4.00 mean score in table 3(4) that transparency is a sign of good governance (Marshall, 2006). The respondents were emphatic at 2.34 mean score as in table 3(5) in rejecting that innovation does not lead to wealth creation. With a grand mean score of 3.22 over a decision score of 3.00, it was found that good management explains good governance. This upholds the argument in the literature that efficient management of resources influences good governance. Regression analysis is used in research to establish the level of relationship between the independent and dependent variables of interest. In regression analysis, there is an important measure $\mathrm{R}^{2}$, which calculates the percentage of variation in the dependent variable accounted for by the independent variable(s). The possible values of $R^{2}$ range from 0 to 1.00 . The closer $R^{2}$ is to 1.00 the greater the percentage of the explained variation. A high value of $\mathrm{R}^{2}$ of about .80 or more would indicate that the independent variable is a good predictor of values of the dependent variable of interest. A low value of about .25 or less would indicate a poor predictor, and a value between .25 and .80 would suggest a moderate predictor Gujarati (2003). In this investigation, the $\mathrm{R}^{2}$ value of .86 suggests that there is a significant linear relationship between good governance and good management. This means that the independent variable explains about 86 percent of the variation in the dependent variable of interest. The remaining variation of about 14 percent was not explained. The goodness-of-fit test of the model is very good with the adjusted $\mathrm{R}^{2}$ value of 0.78 . The value of Durbin-Watson criterion is 2.2 that is within the range between 1.5 and 2.5. On this basis, it can be stated that there is no autocorrelation among the independent variables of interest. The F-test and t-test are significant at 0.05 level. The t-test is greater than 2, therefore, there is a significant positive correlation between good management and good governance in which good management characterized by prudence, competence, among others results to good governance reflected by accountability, transparency, among others. In the circumstance therefore, Ho: was rejected and Hi: accepted to confirm that good management explains good governance. This result supports the essay of Doig (1999) that bad management defined by wide spread public corruption undermines government and leads to bad governance. This result is not an exaggeration because a country that contributes the highest percentage to corruption in Africa annually will not have the capacity for good governance. This is the objective of the study. At this time in the $21^{\text {st }}$ century Nigeria can only start to perceive the aromas of good governance when it minimizes the high propensity of the IOCs to maximize their profits at the expense of society by taking all necessary steps towards cost recovery ceiling which is at 50 percent minimum in other oil-rich countries like Angola. Nigeria can benefit immensely from the New Deep Offshore Act and gain more from PSC if it can enforce disincentives to frustrate a group of highly connected crude oil thieves bent on frustrating the efforts of government in providing good governance. Frauds as high in value as N10trillion in the wage system alone can place government in financial and budget disequilibrium and perpetuate the syndrome of budget deficits that have risen slowly and steadily from N15,134.70 million in 1989 to as high as N9.6trillion in 2019. As Kila (2019) states, corruption is one of the greatest problems in Nigeria, and it has persisted for so long since political independence in 1960 largely because of incompetence. As the war against public mismanagement and corruption rages on, government effort to tackle bloated wage bill through IPPIS and further reduce corruption and cost of governance is imperative. For example, according to Isa (2019) implementation of IPPIS saved for government N274billion between 2017 and 2018 alone. This obviously summarizes the fact that public funds have grossly been micromanaged thereby rendering government impotent and incapacitated in reducing cost of public governance in Nigeria.

\subsection{Scope for Further Study}

Nigeria continues to witness rising budget deficits therefore, there is reason to examine the need of innovation and diversification in public management as avenues for increased internal revenue generation.

\subsection{Recommendations}

i. The fight against corruption should now focus in high public offices like the "Commissions" to reduce the bad corruption cases like the mainagate.

ii. $\quad$ There should be nothing special about permanent offices for some people, because in many cases where these people are permanent in their permanent offices corruption also remains permanent. Nigeria cannot continue to live with $\mathrm{Mr}$. Permanent corruption and expect any magic wand to reduce cost of governance.

iii. Public management must not be the exclusive preserve for retired military, police, and civil servants since most of them have been proved to be corrupt and incompetent. There should be a mixed blend of retired competent private sector players to check corruption and one-way traffic mentality of professional political appointees in the quest to reduce cost of governance.

iv. Creating employment for the youths through the resurrection of abandoned projects and creating new ones would not only provide them with the opportunities to learn, and acquire the necessary experiences to manage and lead, it will also reduce the burden on government in terms of temporary employments and or social investment programmes (SIPs).

v. Since legislators and government leaders usually come from different academic, industrial, and social backgrounds, they should have compulsory re-orientation based on emotional intelligence, vis-à-vis the basic differences between party politics and the architecture of public governance. This will surely 
place the individuals in a position to conduct themselves in the most appropriate manners to enhance accountability, transparency and good governance.

\section{Conclusion}

Despite huge natural resources, Nigeria still witnesses budget deficits and is almost permanently within the palace of the LDCs as the poverty capital of the world because of corruption which makes Nigeria the country with the most people living in extreme poverty at 86 million in sub-Saharan Africa. The huge credible evidence of corrupt practices in relation to public financial management in the country does not teach anybody that the country will soon join the league of developed countries of the world. Corruption cases like the GSPA, PSC, and the bloated wage saga are cases that increase cost of governance and reducing the ability of government to provide sustainable basic services. A culture of good management would likely reverse the culture of kleptomania and provide necessary disincentives for crude oil thieves that make so much money and frustrate the plans of government. 110 participants in the study conducted through the exploratory research design provided useful information that was triangulated with secondary data generated for the purpose of the study. Result of data analysis showed significant positive correlation between good governance and good management. This is the objective of the study.

\subsection{Contribution/Originality}

This work is one of the new studies in recent years to find significant positive correlation between good governance and good management. It stresses the necessity for reducing widespread public corruption through good management defined by prudence, innovation and characterized by stewardship leadership to open the gate towards good governance.

\subsection{Acknowledgement}

I thank Professor Alan Doig, for his essays on corruption, good government, good governance, and economic development, which encouraged me to prepare this paper.

\subsection{Research Funding}

No funding was received from any quarters whatsoever for this original investigation, authorship, and/or publication of this paper.

\subsection{Declaration of Conflict of Interests}

This author declares no potential conflicts of interest to this research, authorship, and/or publication of this paper.

\section{References}

Abuh, A. (2019). Reps Summon Brambaifa, Ekere, Alaibe, others over abandoned NDDC Projects. The Guardian, 36(14882): 3 .

Adekoya, A. (2019). Another \$1.2bn liability dangles over Nigeria as Arura Power deal hangs in balance. Vanguard, 26(63933): 9.

Akowe, T. (2019). Reps to Probe N1tr constituency project cash. The Nation, 13(4879): 8.

Akubeze, O. and Umoh, C. R., 2019. "Governance in nigeria and the common good." In A Commique Issued At The End Of The First Plenary Meeting Of The Catholic Bishops Conference of Nigeria (CBCN) at the Resource Centre Catholic Secretariat of Nigeria (CGN) Durumi, Abuja, 10-16 March, 2019. The Mulumba Lady. pp. 45-47.

Alli, Y. (2019a). EFCC begins probe of \$16b power spending. The Nation, 13(4776): 1 and 6.

Alli, Y. (2019b). Alleged N3bn Scam: Let me retire honourably, Oyo-Ita, begs. The Nation Saturday, 13(4773): 2.

Alli, Y. (2019c). Niger Republic alerts FG of \$1.7m cash at Maina's Niamey home. The Nation, 14(4821): 4.

Andreychuck, R. and Jennings, M. (2003). Globalization and governance: Contemplating the global. The Library of Parliament: Ottawa.

Aucoin, P. (1990). Administrative reform in public management: Paradigms, principles, paradoxes and pendulums. Governance, 3(2): 115-37.

Badarocco, J. L. J. (2002). Leading quietly: An unorthodox guide to doing the right thing. Harvard Business School Press: Boston, MA.

Baje, A. O. (2019). Squandering of Nigeria's riches. Daily Sun, 15(4334): 16.

Balogun, M. J. (1983). Public administration in Nigeria: A developmental approach. Macmillan: London. 34.

Beschel, R. P. J. (1995). Developing a strategy for improving the budget process, Workshop report: Reforming the budget process in Zambia lusaka, Ministry of finance (Zambia) and economic development institute. 21-3.

Bissessar, A. M. (1998). Re-engineering the public services of the commonwealth caribbean. International Review of Administrative Sciences, 64(2): 305-26.

Blanchard, K. (1999). Leadership by the book. London Harper Collins.

Block, P. (1993). Stewardship. Berrett Koehler: San Francisco, CA.

Borins, S. (1994). Government in transition: A new paradigm in public administration. Commonwealth Association for Public Administration and Management: Toronto. 
Brown, L., 1999. "Institutional structures and capacity - building for policy formulation and implementation." In Paper Presented at a Seminar on Restructuring the State. Managing Tensions Between Economic Reform and Social Equity Barbados, 7-8 October.

Chiejina, N. (2019). Fed Govt makes N10tr from TSA. The Nation, 13(4728): 7.

Chigbo, M. (2003). The sacking of gaius-obaseki. Newswatch, 38(20): 78-31.

Clark, A. B. (2019). Nigeria's achievements below expectations. The Nation, 13(4817): 28.

Cleary, R. (1992). Models as effective research tools. In D. M. Cavanagha, and G. M. Rodwell (eds) Dialogues in educational research. William Michael Press: Darwin, N. T.: 54-60.

Cossey, D. (2000). Advocacy with parliamentarians in Europe. Choices, $28: 1$.

Cresswell, J. (2009). Research design: Qualitative, quantitative and mixed methods approaches. London Sage Publications.

Dare, S. (2019). New Deep Offshore Act: A New Vista for Nigeria. New Telegraph, 5(2094): 11-12.

DeLozada, A. S. (1999). In pursuit of public accountability in bolivia. In R. Stepenhurst, and S. J. Kpundeh (eds) curbing corruption. Toward a model for building national integrity. The World Bank: Washington, D. C.: $67-86$.

Doig, A. (1999). Corruption, good government, good governance, and economic development: An essay by alan doig. In R. Stepenhurst, and s. J. Kpundeh (eds) curbing corruption: Toward a model for building national integrit. The World Bank: Washington, D. C.: 18-19.

Dorokinsky, W. and Pradhan, S. (2007). Exploring corruption in public financial management. In j. E. Campos and s. Pradhan (eds) the many faces of corruption tracking. Vulnerability at the sector level. The World Bank: Washington, D. C.: 267-94.

Ebimobowei, A., Boro, I. J. and Chigbu, E. (2013). Impact of macroeconomic variables on government bridget deficit in Nigeria: 1981-2010. Journal of Economics and Sustainable Development, 4(6): 127-46.

Edmondson, A. and McManus, S. (2007). Methodological fit in management field research. Academy of Management Review, 32(4): 1155-79.

Egburonu, S. (2019). Controversy as politicians debate cost of governance. How to reduce cost of government. The Nation, 14(4821): 13-14.

Ehiaghe, G. (2019). Cut wasteful spending to pay minimum wage, union tells govt. The Guardian Nigeria News. 36:

Eriye, F. (2019a). Flamboyant Vampires: $22 \mathrm{~m}$ litres of oil amounting to $\$ 1.5$ trillion lost in six months to illegal bunkering, with alleged security connivance. The Nation, Sunday, 14(4786): 19.

Eriye, F. (2019b). Vomit the pension: Court's order on ex-governors collecting both salaries and pension as senators and ministers is welcome. The Nation Sunday, 14(4877): 19.

Folasade-Koyi, A. (2019). Malabu: FG to extradite ex-AGF, Adoke, over N288.6bn oil deal. Daily sun, 15(4322): 6.

Girishankar, N., Hammergren, L., Holmes, M., Knack, S., Levy, B., Litvack, J., Manning, N., Nessick, R., Rinne, J. and Sutch, H. (2002). Governance. In j. Klugman (ed) a sourcebook for poverty reduction strategies. Volume 1 core techniques and cross-cutting issues. The World Bank: Washington, D. C.: 269-99.

Gujarati, D. N. (2003). Basic econometric. 4th edn: McGraw-Hill: New York.

Gulati, M. and Rao, M. Y. (2007). Corruption in the electricity sector: A pervasive scourge. In J. E. Campos, and S. Pradhan (eds) the many faces of corruption: Tracking vulnerabilities at the sector level. The World Bank: Washington, D. C.: 115-57.

Hammergren, L., 1998. "Political will, constituency building, and public support in justice reform." In Office of Democracy and Governance, United States Agency for International Development, Washington, D. C.

Isa, A. (2019). Tackling Bloated Wage Bill Through IPPIS. New Telegraph, 5(2094): 26.

Jibueze, J., Nwisi, R. and Jimoh, A. (2019). EFCC, ICPC: Our battle against graft. The Nation, 13(4728): 3.

Jimoh, A. M. and Akuba, J. (2019). Govt Plans N9.12tr deficit budget for new fiscal year. The Guardian, 36(14882): 1 and 6.

Kaufmann, D. and Dininio, P. (2006). Public sector management. In r. Stepenhurst, n. Johnston, and r. Pelizzo, (eds) the role of parliament in curbing corruption. The World Bank: Washington, D. C.: 22-23.

Keeves, J. P. (1997). Models and model building. In j. P. Keeves (ed) educational research methodology and measurement. An international handbook. 2nd edn: Pergamum: Cambridge U. K. . 43-50.

Kila, A. (2019). War Against Corruption must be systematic-Kila. New Telegraph, 5(2094): 13.

Koutsoyainnis, A. (1977). Theory of Econometric. Macmillan Education Ltd: London.

Mabikke, S. B., 2012. "Africa's wealth of resources blessing or curse." In Expert conference organized at the european academy otzenhansen (saarland) january 18th - 20th 2012.

Maduabum, C. P. (2006). The machinery of government in Nigeria (including the structure and objectives of the federal public service) badagry. Administrative Staff College of Nigeria (ASCON). 1-7.

Mailafia, O. (2019). Fiduciary duty of care over Chinese loans. Vanguard, 26(63933): 31.

Malami, A. (2019). Obono-Obla Carried out 50 illegal investigations-MALAMI. Vanguard, 26(63933): 13.

Marshall, D. (2006). Oversight, in R. Stepenhurst, N. Johnson, and R. Pelizzo (eds) the role of parliament in curbing corruption. The World Bank: Washington, D. C.: 233-34.

McCourt, W. (2008). Public management in developing countries: From downsizing to governance. Public Management Review, 10(4): 467-79.

Meredith, J. (1993). Theory building through conceptual models. International Journal of Operations and Production Management, 13(5): 3-11. 
Nigeria (1999). Constitution of the Federal Republic of Nigeria, (as amended) Government Press, Section: Abuja. 150:

Njoku, D. (2009). Local government administration: Theories and practices. Bonchris Publishers: Owerri. 162-63.

Njoku, D. (2017). Human capital management and corporate ethics: Theories and practices. Kriscona Publishers: Owerri, Nigeria. 349-50.

Nkwopara, C. (2019). Imo assembly probes n3bn missing rural roads equipment. Vanguard, 26(63933): 34

Nwankwo, O. C. (2011). A practical guide to research writing for students of research enterprise. Review edn: Pam Unique Publishers: Port Harcourt.

Nweze, C. (2019a). \$9.6b judgment: Report exposes P and ID, Danjuma’s link. The Nation, 13(4783): 18.

Nweze, C. (2019b). NBSm SMEDAN Survey shows 41.5m MSMEs in Nigeria. The Nation, 13(4728): 37.

Nwizu, G. C. (2002). Studies in modern public administration okigwe. Marco Press. 326-27.

Obodoeze, F. O. (1996). Modern textbook of research methodology. Academic Publishing Company: Enugu.

Ofikhenua, J. (2019a). Governors to Fed Govt: bring N49b Oil thieves to book. The Nation, 13(4879): 9.

Ofikhenua, J. (2019b). Fed Govt eyes 140,000 jobs from NLNG Train 7. The Nation, 13(4791): 41.

Okpalike, C. G. (2018). Restructuring as a socio-political imperative in the continued existence of Nigeria. The Pointer Magazine, 28(6): 6-7.

Onogu, S. (2019). Okorocha; cut number of senators, reps. Let's begin cost-cutting from here. The Nation, 13(4812): 39.

Orekoya, T. (2019). Leadership is everything. The Nation Sunday, 14(4856): 34

Otokpa, R. (2019'). NEITI: Nigeria lost \$42b to oil theft in 10 years. New Telegraph, 5(2094): 1 and 6.

Oyesola, B. (2019). EFCC blames Nigeria's economic woes on corruption. Daily Sun, 15(4326): 36.

Paiko, I. I. (2012). Deficit financing and its implication on private sector investment. The nigerian experience. Arabian Journal of Business and Management Review, 1(9): 45-62.

Saad, W. and Kalakechi, K. (2009). The impact of budget deficits, on money demand: Evidence from Lebanon. Middle Eastern Finance and Economics, 3: 65-72.

Sanusi, M. (2019). FIRS and the challenge of reforms. The Nation, 13(4817): 20.

Shehu, M. G. (2019). Ex-presidents asked for tips to Award Contracts - PRESIDENCY. Vanguard, 26(63933): 5 and 41 .

Sobowale, D. (2019). Leadership, expectations and democracy. The Nation Saturday, 13(4773): 10.

Soyele, O. (2019). EFCC To Auction Diezani’s N14.4bn Jewelry, Others' Leadership. 357: 5.

Stephen, I. (2019). Confronting the unemployment crisis. The Nation, 13(4791): 15.

Transparency International (2006). Handbook: Curbing corruption in public procurement. Available: http://www.transparency.org/global

Tsa, G. (2019). Malabu: EFCC, AGF clash over adoke's extradition. Daily Sun, 15(4326): 40.

Tshiyoyo, M. M. (2012). Leadership and governance imperative for development in the democratic republic of the Congo. Unpublished Ph.D. Thesis Faculty of Economic and Management Sciences, University of Pretoria, Pretoria, South Africa.

Tstsu, T. F. (2016). Energy resource (oil) mismanagement in West-Africa. A Thesis-submitted To The College of Arts and Sciences of Webster University In Partial Fulfillment of The Requirements for the Degree of Master of Arts in International Relations, Accra, Ghana.

Ugo, F. C. (2018). Unmasking the real face of nigerian political system. The Pointer Magazine, 28(6): 9-11.

Umoru, H. (2019). Senate c'ttee, minister, trade words over alleged. N14bn padded money for private firm. Vanguard, 26(63933): 8.

Utomi, J. (2019). Communism, democracy and leadership in Nigeria. Daily Sun, 15(4334): 17.

Wantu, J. and Ogunu, M. (2019). Benue arraigns SIP officials for alleged N226m fraud. EFCC denies indicting federal welfare scheme for corruption. The Guardian, 26(14882): 3.

Ware, G., Moss, S., Campos, J. E. and Noone, G. R. (2007). Corruption in public procurement: A perennial challenge. In j. E. Campos and s. Pradhan (eds) the many faces of corruption: Trackling vulnerabilities at the sector level. The World Bank: Washington, D. C.: 295-334.

Williams, J. (2006). Building parliamentary networks. In $r$. Stapenhurst, $n$. Johnston, and r. Pelizzo (eds) the role of parliament in curbing corruption. The World Bank: Washington, D. C. . 217-26.

$\mathrm{Yu}$, B. T. and Lee, P. K. C. (2012). Quality management framework for public management decision-making. Management Decision, 50(3): 420-38.

Yusuf, I. A. and Chiejina, N. (2019). Custom's raids legal, yielding results: FIRS/EFCC joint taskforce rakes in N28.51b, \& 77.83m from tax defaulters. The Nation, Sunday, 14(4814): 4. 